\title{
Auspicious Offering of Lord Shiva as a Source of Natural Antiviral Compounds against COVID 19: A Review
}

\author{
Yadav Yadevendra ${ }^{1 *}$, Sharma Arun $^{2}$, Sharma Usha ${ }^{3}$, Sharma Khemchand ${ }^{4}$
}

${ }^{1}$ Assistant Professor, P.G. Department of Rasa Shastra \& Bhaishajya Kalpana, Uttarakhand Ayurveda University, Rishikul Campus, Haridwar, India ${ }^{2}$ PG Scholar, P.G. Department of Rasa Shastra \& Bhaishajya Kalpana, Uttarakhand Ayurveda University, Rishikul Campus, Haridwar, India

${ }^{3}$ Associate Professor, P.G. Department of Rasa Shastra \& Bhaishajya Kalpana, Uttarakhand Ayurveda University, Rishikul Campus, Haridwar, India

${ }^{4}$ Professor and Head, P.G. Department of Rasa Shastra \& Bhaishajya Kalpana, Uttarakhand Ayurveda University, Rishikul Campus, Haridwar, India

\author{
DOI: $10.36348 /$ sijtcm.2020.v03i07.001 \\ | Received: 26.06.2020 | Accepted: 03.07.2020 | Published: 08.07.2020
}

*Corresponding author: Dr. Yadevendra Yadav

\section{Abstract}

Offerings of flowers, leaves, fruits, cereals, foods and drinks to the Gods have been spoken about to a great extent in ancient Hindu scriptures such as Puranas and Vedas. These substances also have replete with significant medicinal values. ' Mahamrityunjaya Mantra Japa' means Great Death-conquering Mantra, is a verse (sukta) of the Rigveda. This mantra is addressed to Shiva for warding off death and bestows longevity. Lord Shiva idolizes with some astonishing substances like Bilva Patra, Bhang Patra, Arka Puspa and Ganga Jal in Mahamrityunjaya Mantra Japa'. Medicinal properties like, antimicrobial, antiviral, antifungal, Anti-inflammatory, Analgesic, Anticancer, Antioxidant property of these have been reported by recent researches. In the future, In vitro and In vivo studies on these items of worship show that these may be an answer to non-treatable diseases like autoimmune disorder, viral infection and cancer etc., as these substances have anti-inflammatory, immunomodulation and antimicrobial properties. Exploration of the text of Traditional and complementary medicine might be useful in research of new drug molecules.

Keywords: Antiviral, bacteriophage, cytokine-storm, Cannabidiol, immunomodulation.

Copyright @ 2020: This is an open-access article distributed under the terms of the Creative Commons Attribution license which permits unrestricted use, distribution, and reproduction in any medium for non-commercial use (NonCommercial, or CC-BY-NC) provided the original author and source are credited.

\section{INTRODUCTION}

Indians are incredibly religious and a variety of rituals related to the worship of Gods and Goddesses are performed round the year. Due to their ecological worth and efficient properties, plants, trees, and rivers continue to be used in the holy and social ceremonies of the Hindus. Different species of plants have a unique association with particular deities. Shiva is one of the principal deities of Hinduism. The epithet Nilakantha (Sanskrit; "Nila" = blue, kantha = "throat"). Since Shiva drank the 'Halahala' poison churned up from the Samudra-Manthan to eliminate its destructive capacity. Stunned by his act, Parvati squeezed his neck and stopped it in his throat to prevent it from scattering all over the earth, supposed to be in Lord Shiva's abdomen. However, the poison was so lethal that it changed the colour of his neck to blue [1]. Moreover, in another story Lord Shiva consumed 'Halahal' Posion and later he take Bhang (Cannabis) to nullifies the toxic effect.

Infectious diseases remain the major causes of human and animal morbidity and mortality. The country has experienced the outbreaks and epidemics of many contagious diseases. The emergence of novel human pathogens and the re-emergence of several diseases are of particular concern in the current decade. It is estimated that about $60 \%$ of infectious diseases and $70 \%$ of emerging infections of humans are zoonotic in origin, with two-thirds originating in wildlife. [2] In 2017, the Integrated Disease Surveillance Programme (IDSP) reported 1683 outbreaks of such diseases. The data showed that 71 percent of these outbreaks were caused by viral pathogens[3] Viruses are ultramicroscopic pathogen with its dual form: a living entity inside the host body and non- living inert form outside the host. They are made of only genetic material inside of a protein coating. Viruses cause prevalent infectious diseases such as fever, flu and warts. They also cause severe illnesses such as smallpox, HBV, HCV, Ebola, HIV/AIDS, and Rabies. Viruses behave like hijackers. They invade living, healthy cells and use those cells to replicate themselves. This can damage, kill, or change the cells and make the host sick. Respiratory viral infections, arboviral infections and bat-borne viral 
infections represent three significant categories of emerging viral diseases in India. Infectious aerosols of the tracheobronchial tree represent efficient means for the spread of viral pathogens affecting the respiratory tract [4]. Several bat-borne viruses have also come into prominent notice, best exemplified by Nipah viral disease, severe fever with thrombocytopenia virus (SFTV), as well as Ebola viral disease [5]. Since late December 2019, the coronavirus disease 2019 (COVID19) has received extensive attention for its widespread prevalence [6]. The COVID-19 patients presented typical respiratory symptom (such as fever, cough, and lung damage) and some other associated symptoms such as fatigue, myalgia, and diarrhea [7] the spike (S) protein of SARS-CoV-2 and SARS-CoV enters human alveolar epithelial cells through binding angiotensin-converting enzyme 2 (ACE2) receptor [8].

Previously, the bat is an intermediate host that might have facilitated transfer to humans is identified. However, later findings suggested that the host of coronaviruses is Malayan pangolins (Manis javanica). Metagenomic sequencing identified pangolin-associated coronaviruses that belong to two sub-lineages of SARSCoV-2-related coronaviruses, including one that exhibits substantial similarity to SARS-CoV-2 in the receptor-binding domain[9].

It is crucial to develop antiviral drugs from natural bio-resources to overcome these problems. In this direction, an effort was made to find the antiviral treating potential of some substance offers to Lord Shiva.

Aegle marmelos Corr. (L., Rutaceae), known as "Bael" or "Bilva" in most of the Indian languages. All the parts of this tree, i.e., stem, bark, root, leaves and fruit at all stages of maturity has medicinal importance and about more than 100 compounds have been identified and isolated. Many of these compounds including skimmianine, aegelin, lupeol, cineole, citral, citronellal, cuminaldehyde (4-isopropyl benzaldehyde), eugenol, marmesinin, marmelosin, luvangetin, aurapten, psoralen, marmelide, fagarine, marmin and tannin. Its immature fruit, bark, and leaves have been used in ethnomedicine. The A. marmelos tree has been evaluated for their efficacy against human coxsackie viruses B1-B6. The different concentration of leaves, stem and stem bark, fruit, root and root bark and the pure compound marmelide at a concentration of $62.5 \mu \mathrm{g}$ $/ \mathrm{ml}$, are taken for the In vivo study, whereas, the $\mathrm{IC}_{50}$ of ribavirin, a standard control, is $2000 \mu \mathrm{g} / \mathrm{ml}$. Marmelide is the most effective virucidal agent interfering with the early stage of its replicative phase. [10] As extract and Marmelide of $A$. marmelos have antiviral activities in the initial phase of viral replication with minimum host cytotoxicity in contrary to virucidal chemotherapeutic agents (i.e. ribavirin), which act in the later stages of viral replication and have potent side effects. [11] The ethanolic fraction of the fruits have antiviral activity against the New castle disease virus or Ranikhet disease virus[12]. The fruit extract has exhibited interferon-like activity against the same virus but not against the virus of the pox family[13].

Bhang or Cannabis (Cannabis sativa L., Cannabaceae) is part of the ancient Hindu tradition and custom in the Indian subcontinent. Cannabis is one of the most sacred plants, and it is written in the 4th Veda, i.e., Atharvaveda (1200-1500 BC), where cannabis is described as one of the five most sacred plants on earth. and The text also quoted to it as a 'source of happiness' and a 'liberator' [14]. The consumption of cannabis in various forms for spiritual awakening has been practiced in India for thousands of years, even documented in the scriptures. In some parts of rural India, people attribute various medicinal properties to the cannabis plant. Though, a few years back, its consumption is considered a social stigma. There are numerous mythological stories about Bhang's first appearance on the earth, most of which revolve around the well-known folktale of churning in March 2020 on YouTube of the sea - one of the enduring origin myths in South-East Asia, depicted even on some of the basreliefs at Angkor Wat in Cambodia - when the Hindu gods and demons churned the cosmic sea to obtain Amrita (necter). One version of the story tells that Cannabis plants grew wherever the drops of this nectar fell on the earth (quite telling about its status as a miracle plant). In another version, when Lord Shiva was summoned to drink up the Halahala poison from the churned Ocean, his throat turned blue (Neelkanth), and the agony of the burning poison was too much to handle. His consort, Goddess Parvati, churned some bhang, and he was then relieved of the pain. Much of the medicinal lore around Bhang comes from such stories where Lord Shiva uses the plant to cure an ailment [15]. A Professor of Hebrew University of Jerusalem, Gershom Zajicek, uploaded a video in March 2020 on YouTube and claims, Cannabis indica speeds up Recovery from Coronavirus. Cannabis indica resin is antiviral and inhibits cell proliferation. It contains about 60 cannabinoids. It has higher efficacy than any single compound like tetrahydrocannabinol (THC), or CBD [16]. Although many medicinal applications of cannabinoids and cannabis are related to their anti-inflammatory property, which is, however, a double-edged sword under some diseased conditions. Particularly in viral diseases, the anti-inflammatory activity of THC may put on host immune responses to acute viral infections, leading to the spread of the infection and death in the worst case [17]. The International Association for Cannabinoid Medicine (IACM), Germany, issued a report on the COVID-19 and the use of cannabinoids, that some laboratory reports suggest that cannabinoids may have antiviral effects. CBD had In vitro antiviral activity against the Hepatitis $\mathrm{C}$ virus. CBD inhibited $\mathrm{HCV}$ replication by $86.4 \%$ at a single concentration of $10 \mu \mathrm{M}$ with $\mathrm{EC}_{50}$ of $3.163 \mu \mathrm{M}$ in a dose-response assay. [18] The other 
study shows an indirect antiviral action of CBD against Kaposi's sarcoma-associated herpesvirus (KSHV) using a model of KSHV-infected human dermal microvascular endothelial cells (HMVECs) [19]. In vivo study conducted by Mecha et al. in mice CBD at a dose of $5 \mathrm{mg} / \mathrm{kg}$ administered for 10 days to immediately after infection with Theiler's murine encephalomyelitis virus (TMEV). CBD reversed the harmful effects of neuroinflammation induced by TMEV. But this study does not provide any investigational evidence of the direct or indirect antiviral effect of CBD. [20] CBD can induce apoptosis in mammalian cells [21]. Apoptosis, or programmed cell death of the infected cell, is an unavoidable critical component of host responses to viral infections [22].

With the exponential rise of the worldwide death toll from the coronavirus infection, The Lancet illustrated that "accumulating evidence" indicates "patients with severe COVID-19 might have a cytokine storm syndrome."_Science Daily published a report that hyperinflammatory cytokine storm, relating a surge of immune cells becomes erratic, was likely the primary cause of death in several viral outbreaks, including the 1918-20 "Spanish flu" pandemic. (killed about more than 50 million patients) and, very soon, the H1N1 Swine flu and the so-called Bird flu. Several studies on cannabinoid compounds suggested that Cannabidiol (CBD) and tetrahydrocannabinol (THC) are immunosuppressants. CBD acts as an effective antiinflammatory, reducing cytokine production and inhibiting immune cell function. It is well known that stimulation of the CB2 cannabinoid receptor by THC and its endogenous counterparts can suppress inflammatory reactions. Cannabinoid receptor signaling confers therapeutic effects by downregulating inflammatory cytokine expression. A study on CBD reduced neuro-inflammation in a virus-induced animal model of multiple sclerosis also supports this assertion. [72]. A UK based writer Mary Biles working on CBD Project claimed that: "A new wave of research and mounting anecdotal evidence points towards cannabinoids having an adaptive, immunomodulating effect, rather than just suppressing immune activity" [23].

Arka Puspa (Calotropis gigantea, Asclepiadaceae) is a shrub common in Eastern Asia and Southeast Asia. In Ayurveda, its latex is commonly in various formulations and as a treatment media for metallic and mineral Ash preparations. Its flower is used as offering to please the God Shiva. Bioactive secondary metabolites, e.g., cardiotonic steroids, triterpene alcohols, alkaloids and flavonoids have been isolated from different parts of Calotropis plants and showed various pharmacological properties such as analgesic, hepatoprotective, sedative, antiinflammatory, antidiarrheal, antiasthmatic and anticancer activities[24]. In vitro Antiviral Activities on different strains of Influenza on (+)-pinoresinol 4-O-bD-glucopyranoside, a novel glycoside isolated the latex of Calotropis gigantea shows inhibitory activity by cytopathic effect (CPE) inhibition assay on Madin Darby Canine Kidney (MDCK) cells. In this study oseltamivir, anti-influenza drug used also as standard control drug, reduced virus titers at the late stage (6 to $10 \mathrm{~h}$ ) by blocking the release of progeny virions (Figure 6B), while compound isolated from $C$. gigantea exerted its antiviral effect at the early stage of virus replication (0 to $4 \mathrm{~h}$ ). The glucopyranoside significantly suppressed the translocation of the phosphorylated p65 (pNF-kB) into the nucleus, demonstrating that this compound possesses an inhibitory effect on the virus-induced activation of NF-kB [25].

Ganga River is a lifeline of millions of creatures residing on its bank and regarded as the most respectful pious rivers of Hindus. During $500 \mathrm{BC}$, Hippocrates wrote about the wound healing properties of Ganga water. However, the role of the bath in the treatment of leprosy lead to believe that water was used for curative effects[26]. Antibacterial properties of the waters of Ganga and Yamuna had been characterized by Hankin [27]. Long before the genesis of the concept of bacteriophages developed by d'Herelle [28]. Geological studies have proven that the Himalayas, the origin place of Ganga and Yamuna, had emerged at a location where the Tethys Ocean once existed. Primitive marine fossils high in the Himalayan permafrost as abiotic particles are being released gradually with the melting permafrost to seed source of bacteriophage in Ganga [29]. Bacteriophages or phages are bacterial viruses that invade bacteria and, in the case of lytic phages, disrupt bacterial metabolism and cause the bacterium to lyse. Many enthusiastic beginning of preclinical bacteriophage therapy was conducted on Pseudomonas aeruginosa, Klebsiella ozaenae, Klebsiella rhinoscleromatis scleromatis, Klebsiella pneumonia and Acinetobacter. But out of these studies, a single study was clinically evaluated on Klebsiella so far. [30]. Przybylski et al. show that a Phage preparation poses the feature of novel antiviral agents on adenovirus. Adenoviruses causes a range of illnesses like fever, cold-like symptoms, sore throat, diarrhea, bronchitis, pneumonia and pink eye (conjunctivitis). In this experiment, Escherichia coli phage (T4) and staphylococcal A5/80 phage significantly reduced the expression of type 5 human adenovirus (HAdV-5) genes and synthesis of HAdV-5 DNA was inhibited only by T4 [31]. Johanna M. Sweere, and his team of discovered that Phage-infected $P$. aeruginosa attracted phagocytes to the wound, however, once phagocytes had ingested infected bacteria triggered an antiviral response, rather than an antibacterial. The researchers suggest the mechanism behind this finding. This could be due to the phages producing RNA on the uptake to phagocytes, which triggered TLR3 and TRIF-dependent type I interferon expression [32]. Antimicrobial effects of Phage preparation, which are not directly related to their antibacterial effect and findings, suggested that it 
could be applied in the future in the treatment of fungal and viral infections [33].

Datura (Datura metel Linn., Solanaceae) flowers and fruit is known as devil's trumpets, thornapple, hell's bells, moonflower are used to adorn Shivling in many Shiva temples. This is mentioned in the Vamana Purana that the Dhatura flower appeared from the chest of Shiva. Datura metal, although known for its toxicity, also contains medicinal properties. It is also used in folklore and traditional medicine. In Ayurvedic medicine, smoking of Datura to relieve dyspnea likes conditions such as asthma [34]. Phytochemical isolated are tannins, phlobatanins, cardiac glycosides, carbohydrates and flavonoids; tropane alkaloids such as hyoscyamine, atropine scopolamine, anisodamine and anisodine. Phytopharmacological studies on different types of extracts have suggested that $D$. metal has antiasthmatic, cytotoxic, antioxidant, antibacterial, antifungal, spasmogenic, anti-inflammatory, antigout, insecticidal, antifertility properties [35]. Atropine also reported having antiviral activity. It inhibits the growth of enveloped viruses such as herpes simplex virus, influenza virus, new castle disease virus, sindbis, vaccinia, adenovirus, and Japanese encephalitis virus [36]. Atropine also blocks the glycosylation of viral proteins of the herpes virus, and hence the production of new infectious virus particles (virions). Virions formed in the presence of atropine are noninfectious[37]. In vitro antiviral activity study of $D$. metel Linn. fruit and seed reveal extracts have potential against the rabies virus. In this study, antirabies activity was assessed by the cell culture method (RFFIT) and molecular method (PCR), though toxicity was performed by MTT assay technique on the Vero cell line. It was observed that $100 \%$ inhibition at $5 \mathrm{mg} / \mathrm{ml}$ and IC50 (50\% inhibition) was found to be $2.5 \mathrm{mg} / \mathrm{ml}$ of D. metel Linn. fruit (soxhlet and cold) extract. Although the effect of seed extract was half to whole fruit extract in viral load reduction.

Ber (Zizyphus mauritiana, Rhamnaceae). Its names in different languages are - Indian Jujube in English; Badri in Sanskrit; ber, bor in Hindi. The tree is linked with Lord Shiva, whose worship is considered incomplete without an offering of the jujube fruit, especially during 'Mahashivaratri'. Jujube fruit is offered to Lord Shiva, as it is symbolic of longevity and fulfillment of desires. It is a small evergreen tree. The ripe fruit is very nutritious and is consumed raw. Medicinally, it is used as hypnotic-sedative, antibacterial, antifungal, anti-inflammatory, antioxidant, cardiotonic, and wound healing properties. In this plant, 64 alkaloids, 16 glycosides and flavonoids, 14 terpenoids and other ethnopharmacological compounds are present. Each ingredient has unique and multifactorial properties. Betulinic acid, a pentacyclic triterpene found in Z. mauritiana, possesses a wide range of biological and medicinal properties such as antihelmintic, antinociceptive, antibacterial, antimalarial, anti-inflammatory, and anticancer activities. In vitro Study on Betulinic acid showed the anti-influenza viral activity at a concentration of $50 \mu \mathrm{M}$ without significant cytotoxicity in Influenza A/PR/8 virus on human lung adenocarcinoma epithelial cell line. In vivo model in mice, betulinic acid significantly diminished pulmonary pathology, including increased necrosis, numbers of cells involved in inflammation and pulmonary oedema induced by virus-infected compared with vehicle or standard control oseltamivir. IFN- $\gamma$ level, a factor for innate and adaptive immunity in viral infection, is down-regulated after treatment of betulinic acid in mouse lung. Its derivatives have shown a new therapeutic agent for the treatment of HIV infection [38] Also, betulinic acid has been found to have antiinflammatory activity. [39] Triterponic acid, betulinic acid, Oleanolic acid is known to have antitumor effects[40].

Dahi (Curd) is a traditional fermented milk product prepared from cow's or buffaloes milk. Lord Shiva is described in the Brahma-Samhita to be like curd. [41] It is considered in the Hindu literature that Abhishekam to Shiva Lingam with Curd - Gives Good Children, Blessing for children. So many research works have been performed to prove the medicinal therapeutic values in various diseases due to presence of electrolytes as $\mathrm{Na}, \mathrm{K}, \mathrm{Mg}, \mathrm{Ca} \& \mathrm{Fe}$ and Vitamins as A, C, D \& B complex and various strains of Lactobacillus \& Bifidobacterium and digestive enzymes [42] The number of different Lactobacillus bacteria isolated from curd preparations in India is as high as 250 species [43]. Numerous protective mechanisms have been proposed against invasion pathogens by Lactobacillus \& Bifidobacterium. These include secreted bacterial metabolites (lactic acid, hydrogen peroxide, and bacteriocin and bacteriocin-like substances, short-chain fatty acids and polysaccharides), stimulation of innate immunity, and competition for epithelial cell receptors. Another most important characteristic of lactobacilli is their ability to colonize epithelial and mucosal cells, thereby preventing invasion by pathogens of these cells. Lactobacilli might inhibit viral multiplication via competition for attachment to cell receptors or via induction of epithelial cells to produce antimicrobial substances. Exopolysaccharides (EPS) synthesized by lactobacilli to differentially modulate immune responses. Recent studies show that the L. delbrueckii TUA4408L and its EPS differentially modulate the antiviral innate immune response triggered by the stimulation of Toll-like receptor 3 (TLR3) that leads to activation of interferon regulatory factor (IRF)-3 and nuclear factor-kB (NF-kB) and also improved expression of the antiviral factors interferon (IFN)-b, Myxovirus resistance gene A (MxA) and RNase L [44]. Influenza, commonly called as 'flu' is a contagious respiratory disease. Virus infection to the host respiratory tract mucosa causes excessive production of 
inflammatory cytokines in the lung (cytokine storm), and this causes a severe clinical condition due to an inflammation in the lung [45]. In vivo study on rats shows that pretreatment of live or non-live (Heat-killed) Lactobacillus acidophilus strain L-92 (L-92) cells had protective effects against influenza virus infection. Live L-92 decreased the figure of neutrophils in the lung and suppressed lung mass, leading to the subsequent deterioration of consolidation scores of the lung. Cytokines and chemokines, eotaxin, macrophage colony-stimulating factor, IL-1b, RANTES (regulated on activation, normal $\mathrm{T}$ cell expressed and secreted) and interferon- $\alpha$ were markedly increased in the lung: IL-17 was expressively increased in Peyer's patch of the live L-92 group in comparison to the control group. N.K. activity before the virus infection was higher in the nonlive group compared with the live group. This suggests that the reduction of the virus based on N.K. activitydependent innate immunity was more in the non-live group than in the live group. [46]. In vitro antiviral activity on MDCK cell line showed that live cell, nonlive (heat-killed) and cell-free supernatant (CFS) of $L$. plantarum YML009 has effective antiviral activity. The antiviral efficacy of $L$. plantarum YML009 was compared to be more effective than positive control i.e., oseltamivir [47]. Human respiratory syncytial virus (RSV) is the major causative virus of bronchiolitis and pneumonia in children. In vitro, a study on Lactobacillus gasseri SBT2055 (LG2055) exhibits antiviral activity against RSV. Also, the result of the In vivo study in mice does decrease of RSV titer in the lung, while body weight was not reduced after virus inoculation. Additionally, the elevated expression of pro-inflammatory cytokines in the lung upon RSV infection decreased after LG2055 administration. Moreover, interferon and interferon-stimulated genes were upregulated by LG2055 treatment [48]. A similar, in vivo study on with live and heat-killed Lactobacillus rhamnosus G.G. (LGG) via Intranasal pre- and posttreatment of neonatal mice reveals that an immune modulation in respiratory viral infection significantly improves neonatal mice survival after influenza virus infection [49]. Specifically, upregulates type I IFN pathways ameliorate the symptoms of respiratory viral infection or allergic disease. [50] Coxsackie viruses B (CV-B) cause spastic paralysis and can infect many different tissues, such as the central nervous system, liver, endocrine and exocrine pancreas, brown fat, and striated muscle in human. In vitro inhibiting activity against CV-B4 was observed in three experimental conditions (pre-incubation, competition and postinfection assay) were used on HEp-2 cells (human laryngeal carcinoma). The impact of live bacteria, heattreated bacterial cells and cell-free supernatant (CFS) exhibit the reduction of $90 \%$ to $95 \%$ of CV-B4 E2induced cytopathic effect (CPE), compared to control. Other strains of Lactic acid-producing bacteria show antiviral property against enteroviruses like Coxsackievirus A and Enterovirus 71 by Bifidobacterium adolescentis against Coxsackievirus
B3 (CV-B3) [51]. Herpes simplex virus (HSV-2) is responsible for genital herpes. HSV-2 produces localized lesions on mucus membranes and skin of an infected human [52]. Lactobacillus crispatus inhibit the access of the virus into cells by trapping HSV-2 particles. Simultaneously, colonization of L. crispatus on the surface of the cell could block HSV-2 receptors and prevent viral access to cells in early infection phases [53]. Viral gastroenteritis is commonly caused by the rotavirus, adenovirus, astrovirus and norovirus [54]. In vitro study on Lactobacillus and Bifidobacterium of probiotics against rotavirus by plaque assay demonstrated considerable antiviral activity compared to the control group [55]. In vitro efficacy of probiotic strains study of Bifidobacterium breve M-16V, Lactobacillus acidophilus NCFM, Lactobacillus helveticus R0052, or Lactobacillus salivarius PS2 on rotavirus infection was a screen. In this experiment, days $2-14$ of the life of all four strains of Lactobacillus, rats were received RV SA-11 orally on day five. All Lactobacillus strains reduced the viral elimination one-day post-inoculation in comparison to the control group. [56] A research team of Nam Joo HA, Kang Oh Lee \& Do Kyung Lee of Sahmyook University-Industry-Academic Cooperation Foundation fond Anti-HBV effect of Bifidobacterium adolescentis SPM 0212 has antiviral activity against HBV and filled a patent [57].

Madhu (Honey): The Shivalingam is bath by in a mix of milk and Honey. This mixture drink is as auspicious and as nutritious. In Honey, several bioactive compounds have been identified, which contributed to its therapeutic activity. Honey is a natural antioxidant with antibacterial and anti-inflammatory properties. Pollen, wax, organic acids, lactones, minerals, vitamins, amino acids, enzymes, and pigments are other constituents in Honey. Various studies have shown that Honey contains significant variation in contents of different bio-chemicals according to floral sources, climatic conditions and species of the honey bee, which contribute to different characteristic colours, tastes, aromas and bioactivities [58]. Honey is used in almost all traditional systems of medicine and now it is modern medicine too. In Ayurveda, it is used for the treatment of respiratory diseases, diabetes, eye diseases, wounds, and skin disease. Honey has an inhibitory effect on aerobic and anaerobic bacteria, yeast, fungi and viruses. Microbinhibitory constituents of Honey are due to the high concentration of sugar, low $\mathrm{pH}(\square 4), \mathrm{H}_{2} \mathrm{O}_{2}$ chysin, defensing-1, rutin and methylglyoxal. The results of the In vitro study showed that inhibitory effects of Honey, royal jelly, and acyclovir have the highest on HSV-1 at concentrations of 500,250 , and $100 \mu \mathrm{g} / \mathrm{mL}$ of, respectively. In addition, Honey, royal jelly, and acyclovir decreased the viral load from 70,795 to 43.3 , 30 , and $0 \mathrm{PFU} / \mathrm{mL}$ at a concentration of $100 \mu \mathrm{g} / \mathrm{mL}$, respectively [59]. Local application of Honey on infected surgical wounds were made on the dorsum of 
mice and infected with $S$. aureus or Klebsiella sp. The wounds were treated four times in day application and appropriate local antibiotics are used for comparison with control values. Similarly, Honey is assessed for Bacterial conjunctivitis due to E. coli, Proteus sp., $S$. aureus, Klebsiella sp., and $P$. aeruginosa was induced in rats. Conjunctival application of Honey four compared with standard control. Application of Honey into infective conjunctivitis reduced swelling, redness, pus discharge and time for the abolition of bacterial infections [60]. In vitro experiment showed that Honey, royal jelly has the maximum inhibitory effects on Herpes simplex virus type $1(\mathrm{HSV}-1)$ at concentrations of 500 and $250 \mu \mathrm{g} / \mathrm{mL}$, respectively and significantly reduced the viral load. Acyclovir is standard control [61]. Anti-influenza viral activity of Manuka honey reveals that it inhibited influenza virus multiplication for this observation oseltamivir is considered as Standard control [62]. In vitro Antiviral activity of Honey at concentrations of $5 \%$ and higher had a full inhibitory effect on Herpes Simplex Virus Honey Type 1 (HSV-1) [63]. In vitro Anti-influenza viral effects of Manuka honey shows that efficiently inhibited Influenza virus A/WSN/33 $(\mathrm{H} 1 \mathrm{~N} 1)$, virus replication because of its virucidal effects. The simultaneous use of oseltamivir was reduced to approximately 1/1000th. This illustrates the supra additive Synergistic effects of Honey to Antiviral drugs [64].

Candana (Sandal Wood): "Chandana" is a high fragrance wood. The East Indian Sandalwood tree, Santalum album L. has been widely used. In the Indian traditional medicine system Ayurveda, white sandalwood has mostly been used as a demulcent, diuretic, and mild stimulant [65]. In an In vitro study, sandalwood oil demonstrated antiviral activity against herpes simplex viruses (HSV)-1 and 2 in a dosedependent manner through inhibition of viral replication. [66] Single-cell and somatic embryo suspension cultures of Indian sandalwood tree grown in airlift bioreactors and shake-flask cultures as an alternative and renewable resource of shikimic acid, the precursor for the industrial-scale synthesis of Tamiflu, the sole commercially available neuraminidase inhibitor drug against Influenza A virus [67].

\section{DISCUSSION}

Hindu mythology is narrated in the forms of stories in scriptures like Veda, and Purana. These stories have some scientific background. Likewise, Samudra Manthan (Churning of the sea) is to get "Amrita", the nectar of immortality. During churning, a lethal poison "Halahala" also comes out from sea before Amrita. Biological science confirms that life was originated from the sea. The virus is the first biological creature of the earth by abiogenesis in evolutionary history. But, it is also true most of the viral diseases are highly contagious and the threat to higher animals and human beings. The etymology of the virus is a Latin word referring to poison and other noxious liquids, from the same Indo-European base as Sanskrit [68]. In the Hindi languages virus is known as "Vishanu", means minute particle of poison. Halahala poison may be a collection of highly contagious virus having the capacity of causing severe respiratory tract infection in humans. Herbs offered to please the lord shiva might treat the Halahala poisoning. These drugs stop the spread of viruses in the lower part of the respiratory tract and check it at pharynx and larynx. Halahala is not a minera, 1 animal or plant poison because it is originated from the sea. Bluish discoloration of the neck represents that it is has a deleterious effect of the respiratory tract. It is also true that so many endemics are occurred in the coastal area and having viral origin like Nipha, Sars Cov2, and Japanese encephalitis etc. These diseases can be treated by the use of herbal and traditional medicines because they are used to treat these conditions since ages.

But have you ever wondered why? Rituals are usually based on ancient traditions that have multiple aspects. Most of the herbs and liquids that are used in Hindu rites are auspicious and nutritious at the same time. These substances also have medicinal qualities. The substances depicted above also have great potential for the development of novel drugs for bacterial and fungal infection. The immunomodulation and antiinflammatory action of these might be used for the genesis of Anticancer medicine. Cannabis and wood apple also have radioprotective activity. The Scientists of the whole world are trying to develop effective medicine for SARS CoV2 viral infection. These herbs and foods might be able to give drugs for COVID 19. In the treatment of $7^{\text {th }}$ Vega (phase) of poisoning Acharya Charka mentioned that, herbal poison is given for the treatment of venomous animal bite, and vice versa is also true [69]. Most of the animal bites are deadly due to infection of bacteria and viral reside in the animal. Very few cases are due to venom. These bites were treated by herbs and herbo-mineral formulations in Ayurveda but never tested on scientific parameters. In rural and remote areas of India, patients are treated by these medicines.

Endemic and pandemic diseases are known as 'Janapadoddhvamsa', 'Janmara' and 'Marka'. The common factors which affect the mass population are Vayu (air), Udaka (water), Desha (land) and Kala (season). To manage Janapadoddhvamsa, it is advised to include the usage of Rasayana therapy, Panchkarama procedures, Sadvrit Paalan (code of right conducts) and Aachara Rasyana i.e. behavioral therapy, Ushana udaka-pana (Drinking of lukewarm water) and Aptarpana (Emication therapy) patient having medium strength of vigor [70]. Therefore, it should be useful for the betterment of the COVID-19 patient's life and treatment.

In classical Ayurvedic literature, the infectious diseases are mentioned under the term, "Aupasargik 
Rogas". Acharya Sushruta, during the description of Kustha Nidana Chapter (Etiological factors of Skin Diseases) very beautifully illustrated that four diseases such as Skin diseases, Fevers, Tuberculosis and Conguntivitis are transmitted from human to human by the touch of body parts, exhalation, sharing of food, sharing of bed, clothing, garland and body lotions [71]. COVID 19 is a pandemic disease, and spread occurs via human to human.

\section{CONCLUSION}

Fever of COVID 19 is Aupasargik Rogas and reseason for Janapadoddhvamsa. The development of resistance against antiviral agents has augmented a threat to the public health sector. It will be increased when the novel viral diseases are emerging. So the development of new antimicrobial infection is challenging, as it takes decades of years of tedious labor and high skill to develop a new drug molecule. A combination of several phytochemicals may be the medicine of developed resistant microbes because, before the development of modern medical science, the whole world depends on these herbs. From these herbs, so many drug molecules were isolated from it. But all ancient medical science of believes in the combination of two or more herbs or minerals with herbs. So the chance of development of resistance is minimum. Phytochemical extracted from Curcuma Longa and Ocimum Sanctum are now used in modern medicine for the treatment of Cancer, Inflammation and bacterial infection. Strains of Lactobacillus are used to treat gastroenteritis, the reestablishment of healthy gut flora and vaginal infections etc. So these auspicious offering shows their high medicinal value. The motto behind the puja (worship) with a specific substance is scientific, but still, we have to evaluate and validate based on science.

\section{REFERENCES}

1. https://en.wikipedia.org/wiki/Shiva, Cited 12-0420.

2. World Health Organization. (2011). Asia Pacific strategy for emerging diseases: 2010. Manila: WHO Regional Office for the Western Pacific.

3. Integrated Disease Surveillance Programme. (2020). Ministry of Health \& Family Welfare, Government of India. Available from: http://idsp.nic.in/index4.php?lang=1\&level= 0\&linkid=406\&lid=3689, Cited 12-04-2020.

4. Hien, T. T., Liem, N. T., Dung, N. T., San, L. T., Mai, P. P., Chau, N. V. V., \& Khoa, D. B. (2004). Avian influenza A (H5N1) in 10 patients in Vietnam. New England Journal of Medicine, 350(12), 1179-1188.

5. Gopalakrishnan, R., Sureshkumar, D., Thirunarayan, M. A., \& Ramasubramanian, V. (2013). Melioidosis: an emerging infection in India. J Assoc Physicians India, 61(9), 24-6.
6. Gralinski, L. E., \& Menachery, V. D. (2020). Return of the Coronavirus: 2019nCoV. Viruses, 12(2), 135.

7. Huang, C., Wang, Y., Li, X., Ren, L., Zhao, J., Hu, Y., ... \& Cheng, Z. (2020). Clinical features of patients infected with 2019 novel coronavirus in Wuhan, China. The lancet, 395(10223), 497-506.

8. Zhou, P., Yang, X. L., Wang, X. G., Hu, B., Zhang, L., Zhang, W., ... \& Chen, H. D. (2020). A pneumonia outbreak associated with a new coronavirus of probable bat origin. nature, 579(7798), 270-273.

9. Lam, T. T. Y., Jia, N., Zhang, Y. W., Shum, M. H. H., Jiang, J. F., Zhu, H. C., ... \& Li, W. J. (2020). Identifying SARS-CoV-2-related coronaviruses in Malayan pangolins. Nature, 1-4.

10. Badam, L., Bedekar, S., Sonavane, K. B., \& Joshi, S. P. (2002). In vitro antiviral activity of bael (Aegle marmelos Corr) upon. Journal of Communicable Diseases, 34, 88.

11. Fenner, F.J., Gibs, E.P.J., Murphy, F.A., Rott, R., Studdart, M.J., White, D.(1993). Veterinary virology. 2 ed. (Academic Press Inc,) London, UK 1993, 301.

12. Dhar, M. L., Dhar, M. M., Dhawan, B. N., Mehrotra, B. N., \& Ray, C. (1968). Screening of Indian plants for biological activity: Part I.

13. Babbar, O. P., \& AR, M. (1982). Evaluation of plants for antiviral activity.

14. https://theculturetrip.com/asia/india/articles/bhanga-story-of-divine-intoxication/, visited 12-04-2020.

15. https://theculturetrip.com/asia/india/articles/bhanga-story-of-divine-intoxication/, Cited 12-04-2020.

16. https://www.researchgate.net/publication/33974685 3_Cannabis_Indica_speeds_up_Recovery_from Coronavirus, visited 12.04-2020.

17. Reiss, C. S. (2010). Cannabinoids and viral infections. Pharmaceuticals, 3(6), 1873-1886.

18. Lowe, H. I., Toyang, N. J., \& McLaughlin, W. (2017). Potential of cannabidiol for the treatment of viral hepatitis. Pharmacognosy research, 9(1), 116.

19. Maor, Y., Yu, J., Kuzontkoski, P. M., Dezube, B. J., Zhang, X., \& Groopman, J. E. (2012). Cannabidiol inhibits growth and induces programmed cell death in kaposi sarcomaassociated herpesvirus-infected endothelium. Genes \& cancer, 3(7-8), 512-520.

20. Mecha, M., Feliú, A., Iñigo, P. M., Mestre, L., Carrillo-Salinas, F. J., \& Guaza, C. (2013). Cannabidiol provides long-lasting protection against the deleterious effects of inflammation in a viral model of multiple sclerosis: a role for A2A receptors. Neurobiology of disease, 59, 141-150.

21. Śledziński, P., Zeyland, J., Słomski, R., \& Nowak, A. (2018). The current state and future perspectives of cannabinoids in cancer biology. Cancer medicine, 7(3), 765-775.

22. Orzalli, M. H., \& Kagan, J. C. (2017). Apoptosis and necroptosis as host defense strategies to 
prevent viral infection. Trends in cell biology, 27(11), 800-809.

23. https://www.projectcbd.org/science/cannabis-andimmune-system, cited 04-04-2020.

24. Silva, M. C. C., da Silva, A. B., Teixeira, F. M., de Sousa, P. C. P., Rondon, R. M. M., Júnior, J. E. R. H., ... \& de Vasconcelos, S. M. M. (2010). Therapeutic and biological activities of Calotropis procera (Ait.) R. Br. Asian pacific journal of tropical medicine, 3(4), 332-336.

25. Parhira, S., Yang, Z. F., Zhu, G. Y., Chen, Q. L., Zhou, B. X., Wang, Y. T., ... \& Jiang, Z. H. (2014). In vitro anti-influenza virus activities of a new lignan glycoside from the latex of Calotropis gigantea. PloS one, 9(8), e104544.

26. Kloss, J. (1939). Back to Eden. Back to Eden books, Loma Linda

27. Hankin, E. H. (1896). L'action bactericide des eaux de la Jumna et du Gange sur le vibrion du cholera. Ann Inst Pasteur, 10(11).

28. d'Herelle, M. F. (1961). Sur un microbe invisible antagoniste des bacilles dysentériques. Acta Kravsi.

29. Khairnar, K. (2016). Ganges: special at its origin. Journal of Biological ResearchThessaloniki, 23(1), 1-2.

30. Sulakvelidze, A., Alavidze, Z., \& Morris, J. G. (2001). Bacteriophage therapy. Antimicrobial agents and chemotherapy, 45(3), 649-659.

31. Przybylski, M., Dzieciątkowski, T., Borysowski, J., Międzybrodzki, R., \& Górski, A. (2019). Inhibitory effects of bacteriophage preparations on adenoviral replication. Intervirology, 62(1), 37-44.

32. Sweere, J. M., Van Belleghem, J. D., Ishak, H., Bach, M. S., Popescu, M., Sunkari, V., ... \& de Vries, C. R. (2019). Bacteriophage trigger antiviral immunity and prevent clearance of bacterial infection. Science, 363(6434).

33. Górski, A., Bollyky, P. L., Przybylski, M., Borysowski, J., Międzybrodzki, R., JończykMatysiak, E., \& Weber-Dąbrowska, B. (2019). Perspectives of phage therapy in non-bacterial infections. Frontiers in Microbiology, 9, 3306.

34. Barceloux, D.G.(2008). Medical Toxicology of Natural Substances: Foods, Fungi, Medicinal Herbs, Plants, and Venomous Animals. General and Introductory Medical Science: John Wiley and Sons, Los Angeles, California, 1877-8.

35. Mandal, B. K., \& Shah, A. (2013). A review on Pharmacological action and Use of Plant Datura. Univer J Pharm, 2(2), 47-51.

36. Alarcón, B., González, M. E., \& Carrasco, L. (1984). Antiherpesvirus action of atropine. Antimicrobial agents and chemotherapy, 26(5), 702-706.

37. Dang, Z., Ho, P., Zhu, L., Qian, K., Lee, K. H., Huang, L. and Chen, C. H. (2013), New betulinic acid derivatives for bevirimat-resistant human immunodeficiency virus type-1. J. Med. Chem, 56, 2029- 2037.
38. Kalikiti, F. (1998, July). Ziziphus mauritiana in Siavonga district, Zambia. In International Workshop on Ziziphus mauritiana, Harare, Zimbabwe (pp. 13-16).

39. Hsu, H. Y., Yang, J. J., \& Lin, C. C. (1997). Effects of oleanolic acid and ursolic acid on inhibiting tumor growth and enhancing the recovery of hematopoietic system postirradiation in mice. Cancer letters, 111(1-2), 7-13.

40. Yamazaki, Z., \& Tagaya, I. (1980). Antiviral effects of atropine and caffeine. Journal of General Virology, 50(2), 429-431.

41. https://vaniquotes.org/wiki/In_the_Brahmasamhita _it_is_stated_that_Visnu_is_like_milk,_whereas_S iva_is_like_yogurt, Cited 12-04-20

42. Arora, H. (2020). Pea Protein Derived Bioactive Peptides Stimulate Bone Health Promoting Effects.

43. https://www.thehindu.com/sci-tech/science/is-curda-probiotic/article3473679.ece, visited 12-04-2020

44. Kanmani, P., Albarracin, L., Kobayashi, H., Hebert, E. M., Saavedra, L., Komatsu, R., ... \& Aso, H. (2018). Genomic characterization of Lactobacillus delbrueckii TUA4408L and evaluation of the antiviral activities of its extracellular polysaccharides in porcine intestinal epithelial cells. Frontiers in immunology, 9, 2178.

45. Walsh, K. B., Teijaro, J. R., Wilker, P. R., Jatzek, A., Fremgen, D. M., Das, S. C., ... \& Kawaoka, Y. (2011). Suppression of cytokine storm with a sphingosine analog provides protection against pathogenic influenza virus. Proceedings of the National Academy of Sciences, 108(29), 1201812023.

46. Goto, H., Sagitani, A., Ashida, N., Kato, S., Hirota, T., Shinoda, T., \& Yamamoto, N. (2013). Antiinfluenza virus effects of both live and non-live Lactobacillus acidophilus L-92 accompanied by the activation of innate immunity. British journal of nutrition, 110(10), 1810-1818.

47. Park, Y. H., Rather, I. A., Choi, K. H., \& Bajpai, V. K. (2015). Antiviral mode of action of Lactobacillus plantarum YML009 on Influenza virus H1N1.||| Bangladesh Journal of Pharmacology||l, 10(2), 475-82.

48. Eguchi, K., Fujitani, N., Nakagawa, H., \& Miyazaki, T. (2019). Prevention of respiratory syncytial virus infection with probiotic lactic acid bacterium Lactobacillus gasseri SBT2055. Scientific reports, 9(1), 1-11.

49. Kumova, O. K., Fike, A. J., Thayer, J. L., Nguyen, L. T., Mell, J. C., Pascasio, J., ... \& Carey, A. J. (2019). Lung transcriptional unresponsiveness and loss of early influenza virus control in infected neonates is prevented by intranasal Lactobacillus rhamnosus GG. PLoS Pathogens, 15(10), e1008072.

50. Youn, H. N., Lee, D. H., Lee, Y. N., Park, J. K., Yuk, S. S., Yang, S. Y., ... \& Park, S. Y. (2012). Intranasal administration of live Lactobacillus species facilitates protection against influenza virus 
infection in mice. Antiviral research, 93(1), 138143.

51. Arena, M. P., Elmastour, F., Sane, F., Drider, D., Fiocco, D., Spano, G., \& Hober, D. (2018). Inhibition of coxsackievirus B4 by Lactobacillus plantarum. Microbiological research, 210, 59-64.

52. Field, H. J., \& Vere Hodge, R. A. (2013). Recent developments in anti-herpesvirus drugs. British medical bulletin, 106(1), 213-249.

53. Mousavi, E., Makvandi, M., Teimoori, A., Ataei, A., Ghafari, S., \& Samarbaf-Zadeh, A. (2018). Antiviral effects of Lactobacillus crispatus against HSV-2 in mammalian cell lines. Journal of the Chinese Medical Association, 81(3), 262-267.

54. Tran, A., Talmud, D., Lejeune, B., Jovenin, N., Renois, F., Payan, C., ... \& Andreoletti, L. (2010). Prevalence of rotavirus, adenovirus, norovirus, and astrovirus infections and coinfections among hospitalized children in northern France. Journal of clinical microbiology, 48(5), 1943-1946.

55. Kang, J. Y., Lee, D. K., Kim, M. J., Park, J. E., Shin, H. S., \& Ha, N. J. (2013). Antiviral activity of Bifidobacterium longum SPM1205, 1206 and Lactobacillus ruminis SPM0211 against rotavirus.

56. Azagra-Boronat, I., Massot-Cladera, M., Knipping, K., Garssen, J., Ben Amor, K., Knol, J., ... \& PérezCano, F. J. (2020). Strain-Specific probiotic properties of bifidobacteria and lactobacilli for the prevention of diarrhea caused by rotavirus in a preclinical model. Nutrients, 12(2), 498.

57. Bifidobacterium adolescentis spm 0212 having antiviral activity for hepatitis $b$ virus, and pharmaceutical composition for preventing and treating of hepatitis b comprising thereof., https://patents.google.com/patent/US20130259835 A1/en, cited on 04-04-2020.

58. Nugraheni, Z. V., \& Ersam, T. (2017). Bioactive Compounds and their Health Effects from Honey Processing Industries. Food Processing By Products and their Utilization, 309-322.

59. Hashemipour, M. A., Tavakolineghad, Z., Arabzadeh, S. A., Iranmanesh, Z., \& Nassab, S. A. (2014). Antiviral Activities of Honey, Royal Jelly, and Acyclovir Against HSV-1. Wounds: a compendium of clinical research and practice, 26(2), 47.

60. Al-Waili, N. S. (2004). Investigating the antimicrobial activity of natural honey and its effects on the pathogenic bacterial infections of surgical wounds and conjunctiva. Journal of medicinal food, 7(2), 210-222.
61. Hashemipour, M. A., Tavakolineghad, Z., Arabzadeh, S. A., Iranmanesh, Z., \& Nassab, S. A. (2014). Antiviral Activities of Honey, Royal Jelly, and Acyclovir Against HSV-1. Wounds: $a$ compendium of clinical research and practice, 26(2), 47.

62. Watanabe, K., Rahmasari, R., Matsunaga, A., Haruyama, T., \& Kobayashi, N. (2014). Antiinfluenza viral effects of honey in vitro: potent high activity of manuka honey. Archives of medical research, 45(5), 359-365.

63. Ghapanchi, J., Moattari, A., Tadbir, A. A., Talatof, Z., Shahidi, S. P., \& Ebrahimi, H. (2011). The in vitro anti-viral activity of honey on type 1 herpes simplex virus. Australian Journal of Basic and Applied Sciences, 5(12), 849-852.

64. Watanabe, K., Rahmasari, R., Matsunaga, A., Haruyama, T., \& Kobayashi, N. (2014). Antiinfluenza viral effects of honey in vitro: potent high activity of manuka honey. Archives of medical research, 45(5), 359-365.

65. Pande, M. C. (1977). Medicinal oils and their importance. Medicine and Surgery, 17(587), 13.

66. Benencia, F., \& Courreges, M. C. (1999). Antiviral activity of sandalwood oil against herpes simplex viruses-1 and-2. Phytomedicine, 6(2), 119-123.

67. Misra, B. B., \& Dey, S. (2013). Shikimic acid (tamiflu precursor) production in suspension cultures of East Indian sandalwood (Santalum album) in air-lift bioreactor. Journal of Postdoctoral Research, 1(1), 1-9.

68. https://en.wikipedia.org/wiki/Virus, cited 16.04.20.

69. Sastri, K.N. (2006). Vidyotini Hindi commentary and Ayurveddepika Sanskrit commentary of Chakrapanidutta on Charaka Samhita of Agnivesa, Chaukhambha Sanskrit Sansthan,Varanasi, India, Edition, II, 23(50), 634.

70. Sastri, K., \& Chaturvedi, G.(2006). Charak Samhita of Agnivesa, Revised by Charaka \& Dradhabal with elaborated vidyotini hindi commentary Chaukhamba Bharti Academy, Varanasi, edition, 1(3), 691-704.

71. Shastri, A., Susruta, S. (2006). Ayurveda tattva sandipika commentary, Chaukhamha Sanskrit sansthan, Ed 2006, Sutrasthana, Verse no.5/32-33, 251.

72. Martin A. Lee and Tiffany Devitt, https://www.projectcbd.org/medicine/cannabis -cbd-covid-19, cited 04-04-20. 